\title{
Analisis Efektivitas Komunikasi Krisis PT A: Studi Kasus Sangkaan Pengambilan Air Tanah Secara Ilegal
}

\author{
Ardhina Zaiza \\ Institut Komunikasi dan Bisnis LSPR, Jakarta, Indonesia
}

\begin{abstract}
ABSTRAK
Tidak ada organisasi yang kebal terhadap krisis. Pada satu titik, mereka pasti akan mengalami krisis. Keberhasilan organisasi dalam menangani krisis itu sendiri akan bergantung pada bagaimana mereka melakukan manajemen krisis yang tepat, termasuk komunikasi krisis. Penelitian ini adalah studi kasus dari perusahaan minuman terkenal, PT A, yang pernah mengalami krisis dalam bentuk kasus hukum yang berkaitan dengan perizinan lingkungan. Penelitian ini bertujuan untuk melihat efektivitas PT A dalam krisis mereka. Studi ini mengamati proses manajemen krisis berdasarkan tahapan krisis dan menggunakan Situational Crisis Communication Theory (SCCT) sebagai dasar. Meskipun tidak ideal, dapat dikatakan bahwa komunikasi krisis PT A efektif. Ini membuktikan gagasan bahwa setiap krisis itu unik, dan perlakuan terhadap krisis harus disesuaikan dengan pilihan terbaik untuk kondisi pada saat itu.
\end{abstract}

Kata kunci: komunikasi krisis; manajemen krisis; studi kasus krisis; krisis perusahaan; komunikasi perusahaan

\begin{abstract}
No organization is immune to crisis. At one point, they can be sure to experience a crisis. Organizational success in dealing with the crisis itself will depend on how they conduct appropriate crisis management, including crisis communication. This research is a case study from a well-known beverage company, PT A, which had experienced a crisis in the form of a legal case relating to environmental licensing. This study aims to see the effectiveness of PT A in communicating their crisis. The study looked at the crisis management process based on the stages of the crisis and using Situational Crisis Communication Theory (SCCT) as a basis. Although not ideal, it can be said that PT A's crisis communication is effective. This proves the idea that every crisis is unique, and the treatment of crisis must be adjusted to the best choice for the conditions at the time.
\end{abstract}

Keywords: crisis communication; crisis management; crisis case study; corporate crisis; corporate communication

\section{PENDAHULUAN}

Dalam suatu waktu, semua perusahaan — baik yang besar maupun kecil, dikelola secara terbuka maupun tertutup — akan menghadapi krisis (Fink, 2013). Ranah pembelajaran mengenai krisis didominasi oleh studi kasus (Coombs, 2007). Dari studi kasus yang ada, dapat disimpulkan bahwa diperlukan manajemen krisis yang tepat untuk menjaga reputasi perusahaan. Reputasi 
yang tercoreng dapat memberikan konsekuensi besar seperti jatuhnya kepercayaan para pemangku kepentingan yang pada akhirnya akan mempengaruhi kondisi keuangan perusahaan. Fearn-Banks (1996) menekankan pentingnya perusahaan mengembangkan dan menerapkan manajemen krisis dan rencana komunikasi krisis yang efektif. Komunikasi krisis merupakan konstituen penting yang tidak dapat dipisahkan dari manajemen krisis. Komunikasi krisis yang efektif akan memberikan hasil yang positif, sedangkan komunikasi yang tidak efektif akan memberikan hasil negatif.

Pentingnya komunikasi krisis dan mempelajarinya dari studi kasus, membuat peneliti tertarik untuk melakukan studi kasus komunikasi krisis pada perusahaan di Indonesia. Dalam penelitian ini, kasus yang dipilih adalah krisis yang dihadapi oleh PT A, produsen minuman ringan multinasional yang telah beroperasi sejak tahun 1992 di Indonesia, yaitu sangkaan pengambilan air tanah secara ilegal oleh Badan Reserse Kriminal Kepolisian Republik Indonesia (Bareksrim Polri).

Kasus krisis PT A dimulai sejak November 2013 ketika sebuah konsorsium yang diberi nama PJ, melakukan pengaduan terkait aktivitas produksi pabrik PT A kepada Kepolisian. Konsorsium yang menyatakan diri sebagai perwakilan warga RW02 tersebut menyatakan bahwa PT A telah melakukan pengambilan air tanah secara ilegal di area pabrik di salah satu Kabupaten Indonesia, karena Surat Izin Pengambilan Air Tanah (SIPA) untuk beberapa sumur dari 11 sumur yang ada, sudah kedaluwarsa sejak tahun 2011. Akibat aktivitas ilegal terseut, telah terjadi penurunan permukaan air di area pemukiman masyarakat.

Berkat aduan konsorsium PJ, Bareskrim Polri segera melakukan penyelidikan dan penyudikan dan menyatakan dalam konferensi pers bahwa (1) PT A tidak mengantungi izin terkait pengambilan air tanah, (2) PT A melakukan pengambilan air tanah secara illegal, (3) Chief Executive Officer (CEO) PT A bersalah karena membiarkan terjadinya tindakan ilegal tersebut.

Pada akhirnya Bareskrim Polri menyegel sumur dengan izin kedaluwarsa dan menetapkan pimpinan pabrik PT A sebagai tersangka. Kasus terus bergulir hingga Maret 2015, di mana Pengadilan Negeri menggelar sidang putusan sela untuk eksepsi PT A. Di dalam eksepsinya, PT A meminta majelis hakim menunda pemeriksaan pokok perkara karena aspek administrasi terkait dengan surat perpanjangan SIPA yang diajukan oleh PT A sejak tahun 2010 dan 2011, masih tersendat di pemerintah daerah. Eksepsi PT A ditolak oleh majelis hakim dan pemeriksaan pokok perkara terus dijalankan. Di tahun 2015, melalui Mahkamah Agung (MA), Jaksa menuntut pimpinan pabrik PT A dengan hukuman 18 bulan penjara dan denda Rp 200 juta subsider 3 bulan kurungan.

Kasus PT A pada akhirnya menemukan titik terang dengan dibatalkannya Undang-Undang Sumber Daya Air No.7 tahun 2004 oleh Mahkamah Konstitusi (MK) pada 18 Februari 2015 (Saputra, 2017). Pembatalan ini diajukan oleh Pimpinan Pusat (PP) Muhammadiyah secara kebetulan dan tidak berkaitan dengan kasus hukum PT A. Dengan dibatalkannya UndangUndang yang menjerat perusahaan tersebut, maka tuntutan jaksa tidak diterima oleh MA. MA mementahkan tuntutan tersebut pada Januari 2017. 
Berdasarkan uraian latar belakang masalah maka peneliti merasa bahwa kasus ini menarik untuk dianalisa. Secara spesifik, kasus ini dipilih sebagai objek penelitian karena studi kasus komunikasi krisis perusahaan dalam sektor industri makanan dan minuman di Indonesia masih jarang ditemui dan PT A merupakan perusahaan multinasional yang telah beroperasi selama lebih dari 20 tahun di Indonesia.

Melihat signifikansi peranan sektor industri makanan dan minuman pada perekonomian Indonesia, peneliti percaya bahwa studi kasus ini dapat membantu banyak perusahaan di sektor industri serupa untuk belajar dari kasus PT A. Melihat skala PT A yang terbilang besar dan keberadaan yang cukup lama di Indonesia, peneliti juga ingin mengetahui strategi komunikasi krisis yang diterapkan oleh PT A.

Berdasarkan penjelasan sebelumnya, dapat dirumuskan masalah penelitian adalah bagaimana strategi komunikasi krisis yang dilakukan oleh PT A pada kasus sangkaan pengambilan air tanah secara illegal dan bagaimana efektivitas implementasi strategi komunikasi krisis PT A pada kasus sangkaan pengambilan air tanah secara illegal. Melalui rumusan masalah di atas maka yang menjadi tujuan penelitian ini adalah memahami strategi komunikasi krisis PT A pada kasus sangkaan pengambilan air tanah secara illegal dan mengetahui efektivitas implementasi strategi komunikasi krisis PT A dalam menyelasaikan masalah dan melindungi reputasi perusahaan. Berdasarkan tujuan penelitian maka manfaat penelitian ini adalah memberikan kontribusi terhadap pengetahuan mengenai komunikasi krisis, terutama krisis pada sektor industri makanan dan minuman di Indonesia yang tidak banyak dilakukan penelitian sebelumnya. Penelitian ini juga diharapkan mampu memberikan pengetahuan baru dari perbandingan antara teori di dunia akademis dengan praktik nyata. Kemudian manfaat penelitian ini juga memberi wawasan bagi perusahaan lain untuk membantu dalam penerapan strategi komunikasi krisis.

Praktik paling umum yang dilakukan untuk menangani krisis dalam organisasi adalah manajemen krisis. Fearn-Banks (1996, p.2) mendefinisikan konsep tersebut sebagai "perencanaan strategis untuk mencegah dan merespons selama krisis atau kejadian negatifsuatu proses menghilangkan sebagian risiko dan ketidakpastian dan memungkinkan organisasi untuk lebih mengendalikan apa yang terjadi”. Hal konsisten yang ditemukan dalam literatur mengenai manajemen krisis adalah gagasan bahwa krisis memiliki siklus hidup yang digambarkan melalui tahapan dengan urutan yang spesifik. Dalam melakukan manajemen krisis, organisasi perlu memahami setiap tahap krisis ini, karena setiap tahap memerlukan tindakan yang berbeda.

Coombs (2012) menggagas tiga tahapan krisis, yang didapat dengan mengintegrasikan beberapa pendekatan lain seperti milik Fink (1986) dan Mitroff, Shrivastava, \& Udwadia (1987) Tahapan ini terdiri dari empat faktor yang saling terkait yang dapat mempengaruhi efektivitas manajemen krisis yaitu (1) prevention (pencegahan), (2) preparation (persiapan), (3) response (reaksi), dan (4) revision (perbaikan). Tahap pra-krisis yang meliputi tindakan yang perlu dilakukan sebelum krisis terjadi dan terdiri dari 3 sub-tahapan: (1) Deteksi sinyal, 
(2) pencegahan, dan (3) persiapan krisis. Tahap peristiwa krisis, yang dimulai dengan peristiwa pemicu yang menandai berawalnya krisis. Tahap ini memiliki dua sub-tahapan: (1) crisis recognition (pengenalan krisis) dan (2) crisis containment (penahanan krisis).

\section{Gambar 1. Tahapan Krisis}

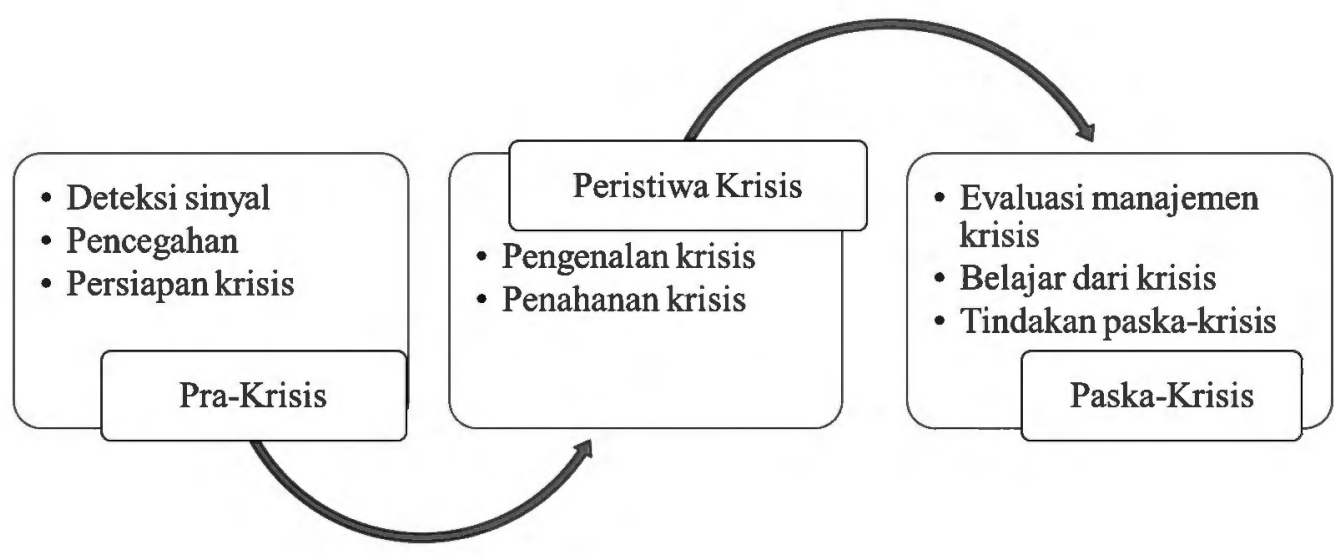

Sumber: Coombs (2012)

Pengenalan terhadap krisis mencakup pemahaman tentang bagaimana peristiwa diberi label dan diidentifikasi sebagai krisis. Penahanan krisis mencakup crisis response (reaksi krisis) yaitu tindakan dan pernyataan yang disampaikan organisasi kepada publik atau berbagai pemangku kepentingan pada saat krisis terjadi agar krisis tidak melebar. Reaksi, adalah aplikasi dari komponen persiapan. Recovery (pemulihan) merupakan bagian dari reaksi terhadap krisis. Pemulihan mengacu pada upaya perbaikan untuk mengembalikan organisasi pada business as usual atau aktivitas operasional normal. Tahap paska-krisis, yaitu tahap di mana krisis berakhir dan dianggap selesai. Pada tahap ini organisasi harus mempertimbangkan apa yang harus dilakukan selanjutnya.

\section{Komunikasi krisis}

Di saat manajamen krisis berkaitan dengan bagaimana organisasi mengelola realita yang terjadi pada saat krisis, maka komunikasi krisis adalah bagaimana organisasi mengelola persepsi mengenai realita tersebut. Dengan kata lain, komunikasi krisis berhubungan erat dengan pembentukan persepsi dan opini publik (Fink, 2013). Apabila krisis telah dikelola dengan baik, tujuan dari komunikasi krisis yang efektif adalah untuk membentuk persepsi publik sesuai dengan realita yang ada. Untuk mempermudah pemahaman mengenai komunikasi krisis yang dibahas dalam beberapa studi dan literatur, penulis akan memaparkan langkah-langkah komunikasi krisis berdasarkan 3 tahapan krisis milik Coombs dan gagasan dari beberapa literatur yang telah dibahas dalam kajian manajemen krisis.

Pada tahap pra-krisis, Fearn-Banks (1996) menyatakan bahwa komunikasi dua arah yang teratur dan program hubungan masyarakat dapat mencegah terjadinya krisis, mengurangi dampak krisis, atau membatasi durasi krisis. Fearn-Banks (2011) juga menilai bahwa budaya organisasi yang berfokus kepada manusia dibandingkan keuntungan dapat menjadi alat pencegahan krisis yang efektif. Budaya tersebut akan mendorong komunikasi yang jujur dan 
terbuka. Hal itu dapat membantu organisasi mendeteksi sinyal krisis yang akan datang. Dalam artikel berjudul 10 Steps to Crisis Communications (2016), konsultan krisis Jonathan Bernstein dari Bernstein Crisis Management juga menyarankan beberapa langkah komunikasi dalam tahap pra-krisis yang harus dilakukan organisasi untuk mendeteksi, mencegah, dan mempersiapkan krisis, di antaranya:

1. Antisipasi krisis dengan bersikap proaktif, misalnya melakukan sesi brainstorming (curah pendapat)

1. Identifikasi tim komunikasi krisis

2. Identifikasi spokesperson (juru bicara)

3. Menetapkan sistem pemberitahuan untuk menjangkau pemangku kepentingan dengan cepat, serta menetapkan sistem pemantauan untuk mengungkap tren negatif yang apabila dibiarkan dapat berubah menjadi krisis.

4. Identifikasi pemangku kepentingan yang berpengaruh pada organisasi

5. Mengembangkan holding statement atau pernyataan sementara yang dapat digunakan saat krisis mencuat

Dalam tahap peristiwa krisis, Fink (2013) menyatakan bahwa sebelum membuat perencanaan komunikasi krisis, organisasi harus dapat dapat melakukan identification (identifikasi), isolation (isolasi), dan management (manajemen atau pengelolaan). Dalam tahapaan krisis menurut Coombs, istilah identifikasi memiliki makna yang sama dengan istilah pengenalan krisis dan istilah isolasi memiliki makna serupa dengan istilah penahanan krisis.

Identifikasi artinya mampu memahami bagian mana dalam krisis tersebut yang harus ditangani dan mana yang dapat dikendalikan, misalnya kepercayaan pelanggan. Sedangkan isolasi atau penahanan krisis dilakukan agar tidak mengganggu area lain dari operasional bisnis, termasuk di antaranya adalah dengan membatasi durasi krisis (Fearn-Banks, 1996).

Tanpa identifikasi dan isolasi krisis yang tepat, organisasi bisa saja pada akhirnya mengelola persoalan yang salah. Setelah krisis berhasil diidentifikasi, baru organisasi dapat membuat crisis communication plan atau rencana komunikasi krisis (Fearn-Banks, 2011). Dalam hubungannya dengan pesan utama dalam rencana komunikasi krisis, Fink (2013) mengutarakan bahwa seringkali dalam krisis yang melibatkan perkara hukum atau litigasi, organisasi memilih untuk tidak menyampaikan pesan atas arahan pengacara. Kebanyakan pengacara berfokus pada pemenangan kasus di pengadilan, tetapi seringkali tidak mengindahkan reputasi organisasi di mata publik. Apabila organisasi membuka diri dan membuat pernyataan, maka ditakutkan akan celah untuk tuntutan hukum.

Bertolak belakang dengan kepercayaan tersebut, Fink menyatakan bahwa menjadi tidak kooperatif dengan menahan informasi adalah tindakan ceroboh. Pemangku kepentingan khususnya media akan mencari sumber lain untuk dijadikan acuan, dan sumber ini berpotensi untuk memberikan informasi menyimpang. Maka dari itu, Pada saat mengelola krisis, sangat penting untuk memilih strategi yang tepat untuk memperbaiki reputasi. Berbagai penelitian telah memberikan rekomendasi strategi, salah satunya strategi yang digagas oleh Coombs (2007) dalam Situational Crisis Communication Theory (SCCT). 
Coombs (2007) menyatakan bahwa pemangku kepentingan melihat behavioral intention atau niat perilaku untuk menilai reputasi sebuah organisasi. Artinya apabila sebuah organisasi dipersepsikan memiliki atribusi akuntabilitas tinggi untuk krisis, akan ada lebih banyak emosi negatif yang dihasilkan.

\section{Gambar 2. Kelompok Krisis Berdasarkan Atribusi}

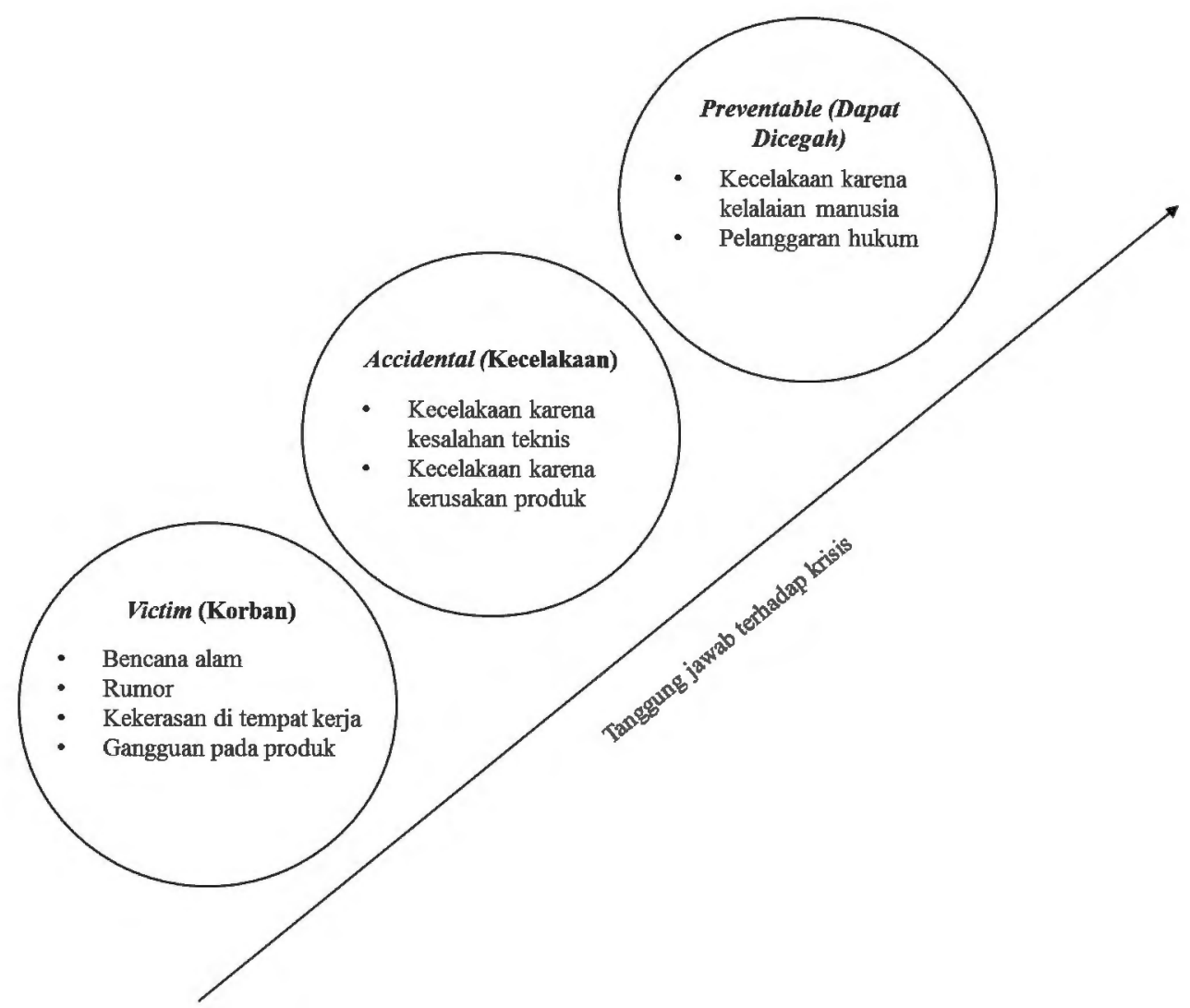

Sumber: Coombs (2012)

Berdasarkan koneksi atribusi tersebut, Coombs mengembangkan SCCT. SCCT memberikan pilihan kepada organisasi untuk memilih strategi respons mereka berdasarkan penilaian terhadap krisis yang dihadapi. Coombs mengidentifikasi 3 kelompok krisis: victim (korban), accidental (kecelakaan), dan preventable (dapat dicegah) terdiri dari 13 jenis krisis yang berbeda, berdasarkan seberapa banyak tanggung jawab krisis yang mereka hasilkan.

Kategorisasi memungkinkan organisasi untuk memiliki satu rencana krisis yang akan bekerja untuk krisis di cluster yang sama. Kelompok victim adalah ketika organisasi tersebut juga menjadi korban krisis. Mereka tidak memiliki kontrol atas ukuran krisis yang akan terjadi meskipun mereka telah meramalkannya. Kelompok accidental adalah saat krisis terjadi karena sebuah tindakan yang dilakukan oleh organisasi yang tidak berniat menciptakan krisis tersebut. 
Krisis pada kelompok terakhir, yaitu preventable, terjadi karena tindakan yang tidak tepat yang dilakukan organisasi, di mana sebenarnya mereka menyadari konsekuensi yang dapat timbul. Begitu sebuah organisasi mengetahui kelompok krisis mereka, organisasi dapat menentukan strategi perbaikan reputasi sebagai bentuk reaksi krisis Coombs.

Tabel 1. Strategi Reaksi Komunikasi Krisis

$\begin{array}{ll}\begin{array}{l}\text { Strategi } \\ \text { Deny Response (Reaksi Mengelak) }\end{array} \\ \begin{array}{ll}\text { Attack the accuser } \\ \text { (Menyerang penuduh) }\end{array} & \begin{array}{l}\text { Hadapi individu atau kelompok yang menyatakan } \\ \text { sesuatu yang tidak benar (misalnya mengancam untuk } \\ \text { menuntut) }\end{array} \\ \begin{array}{ll}\text { Denial (Mengelak) } & \text { Bersikeras menyatakan bahwa tidak ada krisis yang } \\ & \text { terjadi (misalnya pemasok atau rekan bisnis) }\end{array} \\ \begin{array}{ll}\text { Scapegoat (Mencari kambing } \\ \text { hitam) }\end{array} & \begin{array}{l}\text { Menyalahkan pihak lain di luar organisasi atas krisis } \\ \text { Diminish Response (Reaksi Mengurangi) } \\ \text { Excuse (Memberikan alasan) }\end{array} \\ \begin{array}{ll}\text { Mengurangi tanggung jawab dengan menyatakan bahwa } \\ \text { tidak ada niat buruk }\end{array} \\ \begin{array}{ll}\text { Justification (Memberikan } \\ \text { pembenaran) }\end{array} & \begin{array}{l}\text { Mengurangi persepsi mengenai kerusakan yang } \\ \text { dirasakan }\end{array}\end{array}$

Deal Response (Reaksi Menanggapi)

Ingratiation (Mempengaruhi Menyanjung pemangku kepentingan dan mengingatkan orang lain dengan menjadi mereka akan hal-hal baik yang telah dilakukan oleh sosok yang lebih disukai) organisasi

Concern (Mengungkapkan Mengungapkan keprihatinan terhadap korban keprihatinan)

Compassion (Menunjukkan Menawarkan kompensasi untuk korban rasa iba)

Regret (Menunjukan Mengekspresikan perasaan duka penyesalan) Apology (Meminta maaf)

Mengambil tanggung jawab akan krisis dan mengajukan permohonan maaf

Sumber: Coombs (2007)

Coombs memberikan pedoman normatif untuk penggunaan strategi SCCT ketika memberikan reaksi terhadap krisis. Organisasi harus mempertimbangkan riwayat krisis dan hubungan dengan pemangku kepentingan sebelum krisis terjadi, untuk menjadikan strategi yang dipilihan menjadi efektif. Organisasi juga harus menggunakan strategi tersebut secara konsisten.

Dalam tahapan terakhir organisasi harus bisa melakukan langkah-langkah paska-krisis yaitu melakukan evaluasi komunikasi, mempelajari apa yang berjalan dengan baik dan tidak selama 
krisis untuk meninjau apa yang bisa dilakukan lebih baik di kemudian hari. Organisasi dapat melakukan evaluasi pada media, komunitas, dan tim manajemen krisis.

\section{METODE PENELITIAN}

Untuk melakukan penelitian ini, peneliti menggunakan pendekatan penelitian kualitatif dengan metode wawancara mendalam dan analisis dokumen. Wawancara mendalam digunakan untuk mengeksplorasi isu-isu spesifik di bidang krisis komunikasi dari sudut pandang praktisi. Keuntungan dari metode ini adalah kemampuan untuk memperoleh informasi subjektif dari peserta dan memberikan informasi mengenai perasaan, nilai, sikap, dan keyakinan mereka (Stewart, 2002).

Peneliti memutuskan untuk menggunakan wawancara semi terstruktur dengan closed dan open ended questions, di mana narasumber diberikan kebebasan dalam memberikan jawaban. Wawancara mendalam semi-terstruktur dengan pemahaman mengenai penerapan strategi komunikasi krisis.

Narasumber dalam penelitian ini merupakan individual yang tergabung dalam tim krisis PT A untuk kasus ini. Keduanya pernah tergabung dalam tim komunikasi PT A:

1. WS, mantan Head of Corporate Affairs PT A

2. TA, mantan Corporate Affairs Officer PT A

Wawancara terdiri dari setidaknya 9 pertanyaan terbuka dan tertutup. Pertanyaan tertutup digunakan untuk mendapatkan informasi latar belakang, sedangkan pertanyaan terbuka, semiterstruktur digunakan untuk mengeksplorasi isu-isu secara lebih mendalam dan untuk mendiskusikan aspek-aspek spesifik dari krisis komunikasi, misalnya:

1. Strategi komunikasi apa saja yang dikembangkan PT A untuk mendukung manajemen krisis?

2. Strategi apa yang menurut Anda paling efektif digunakan untuk mengurangi dampak krisis PT A?

3. Apa yang akan Anda lakukan secara berbeda dalam merencanakan dan melakukan implementasi strategi komunikasi krisis tersebut?

Selanjutnya metode analisis dokumen dilakukan dengan pengumpulan data dari beberapa dokuman PT A dan pemberitaan media.

\section{HASIL DAN PEMBAHASAN}

Dalam menjabarkan temuan mengenai komunikasi krisis PT A dalam kasus sangkaan pengambilan air tanah secara ilegal, peneliti menggunakan tiga tahapan krisis yang digagas oleh Coombs (2012): (1) pra-krisis, (2) peristiwa krisis, dan (3) paska-krisis.

\section{Tahap pra-krisis}

Dari hasil analisis data, dalam upaya persiapan krisis secara umum, PT A telah memiliki strategi manajemen krisis yang menyeluruh, termasuk komunikasi krisis di dalamnya. Strategi 
ini sudah dimiliki oleh PT A sebelum kasus sangkaan pengambilan air tanah secara ilegal mencuat. PT A menyebut proses pengendalian krisis sebagai Incident Management and Crisis Response (IMCR). IMCR bertujuan untuk mengidentifikasi dan memantau kegiatan yang memiliki potensi untuk berubah menjadi krisis. Dari dokumentasi yang didapat, PT A memiliki panduan alur proses komunikasi IMCR yang memuat pedoman di antaranya mengenai:

1. Jenis insiden

2. Kategori IMCR

3. Contoh klasifikasi insiden

4. Alur eskalasi

5. Kontak utama

6. Susunan tim krisis, dan

7. Contoh laporan

Berdasarkan observasi dan hasil wawancara dengan narasumber WS, PT A juga melaksanakan media monitoring dan pelatihan IMCR setiap tahunnya, termasuk melakukan pelatihan media kepada tim Corporate Affairs di masing-masing area operasional PT A di Indonesia. Namun, dari hasil wawancara dengan narasumber TA, TA menilai adanya kegagalan untuk mendeteksi sinyal dan melakukan komunikasi pencegahan sebelum krisis terjadi. Apabila kedua tindakan tersebut berhasil, maka kecil kemungkinan krisis dapat terjadi. Menurutnya, ketika melihat kembali beberapa kejadian sebelum krisis, ada petunjuk-petunjuk yang dapat memberikan penyadaran:

1. Menilai sikap dan sejarah komunikasi dengan konsorsium PJ: selama ini konsorsium PJ melakukan pendekatan pada PT A untuk dapat mengelola limbah pabrik. Ketika permohonan dari konsorsium tidak dikabulkan, konsorsium PJ sempat melakukan keberatan. Seharusnya ada tindakan pencegahan yang bisa dilakukan, misalnya mencoba membangun hubungan baik melalui mediasi dan komunikasi dua-arah.

2. Komunikasi internal atas pembaruan SIPA: Selain internal PT A yang bertugas melakukan pembaruan izin dan atasannya, hanya segelentir orang yang mengetahui mengenai perizinan tersebut, sehingga tidak ada

3. komunikasi terbuka, tidak ada yang memberikan peringatan atas potensi resiko dari kendala perizinan tersebut pada tim yang bertanggung jawab. pendekatan pada PT A untuk dapat mengelola limbah pabrik.

Meskipun tidak dapat menjamin kebenarannya, TA juga menduga adanya keterlibatan pihak internal yang membekali konsorsium dengan informasi perusahaan yang bersifat rahasia. Hipotesa lainnya adalah ketidaksengajaan karyawan menceritakan permasalahan izin pada pihak konsorsium, tanpa mengetahui bahwa informasi tersebut dapat dimanfaatkan.

\section{Tahap peristiwa-krisis}

Pengakuan atau pengenalan bahwa krisis benar-benar terjadi adalah pada saat pertama kali Bareksrim melakukan penyelidikan fasilitas PT A dan pada saat munculnya banyak pemberitaan di beberapa media. Sesuai dengan kategori IMCR pada alur panduan komunikasi IMCR, ancaman kerugian dan dampak pada reputasi sangat besar, maka PT A mengklasifikasikan kasus sebagai krisis. 
PT A segera melakukan identifikasi mengenai dampak dari peristiwa tersebut, melakukan investigasi dan pengumpulan fakta, serta dan menyusun strategi komunikasi. Pada awal kasus berlangsung, setelah melakukan pengumpulan fakta, strategi komunikasi yang dilakukan oleh PT A adalah dengan memberikan perlawanan pembentukan opini publik yang dibangun kepolisian dengan bertemu media dan mengungkap fakta bahwa dari 11 sumur yang ada, perizinan 7 sumur masih aktif dan 3 masih dalam permohonan dan perizinan telah diajukan oleh PT A namun terkendala karena proses perizinan yang rumit.

Merasa mendapatkan tantangan dari PT A atas klarifikasi tersebut, Bareskrim kemudian kembali mengeluarkan berita dengan pesan utama yang sama: bahwa PT A telah bersalah. Melihat reaksi ini, PT A menyadari bahwa semakin banyak pemberitaan media, semakin banyak pula atensi dan opini publik yang beredar. Publik yang mungkin tadinya tidak menyadari kasus ini akan menjadi tahu dan menimbulkan semakin banyaknya tekanan kepada polisi untuk memaksakan kasus.

Pemikiran tersebut juga didasarkan pada kasus kriminalisasi perusahan lainnya yang serupa, yaitu kasus PT Chevron Pacific Indonesia (CPI) di tahun 2012. Berdasarkan hal tersebut maka PT A menyusun strategi baru. Dari dokumentasi PT A, ada 3 strategi yang dibuat untuk untuk melakukan mitigasi resiko. Pada periode ini setidaknya sudah ada 28 pemberitaan di media mengenai kasus ini.

1. Strategi legal: mengatasi tuduhan kriminal melalui perwakilan legal dan menjaga kepatuhan terhadap prosedur penyidikan polisi

2. Strategi proses operasional: mempertahankan operasi bisnis normal, memberikan kejelasan proses penyidikan kepada manajer fungsional

3. Strategi perlindungan reputasi perusahaan: melakukan tindakan pencegahan dengan media dan membangun pemahaman bersama dengan para pemangku kepentingan utama

\section{Gambar 3. Strategi Komunikasi PT A untuk Kasus Sangkaan Pengambilan Air Tanah Secara Ilegal}

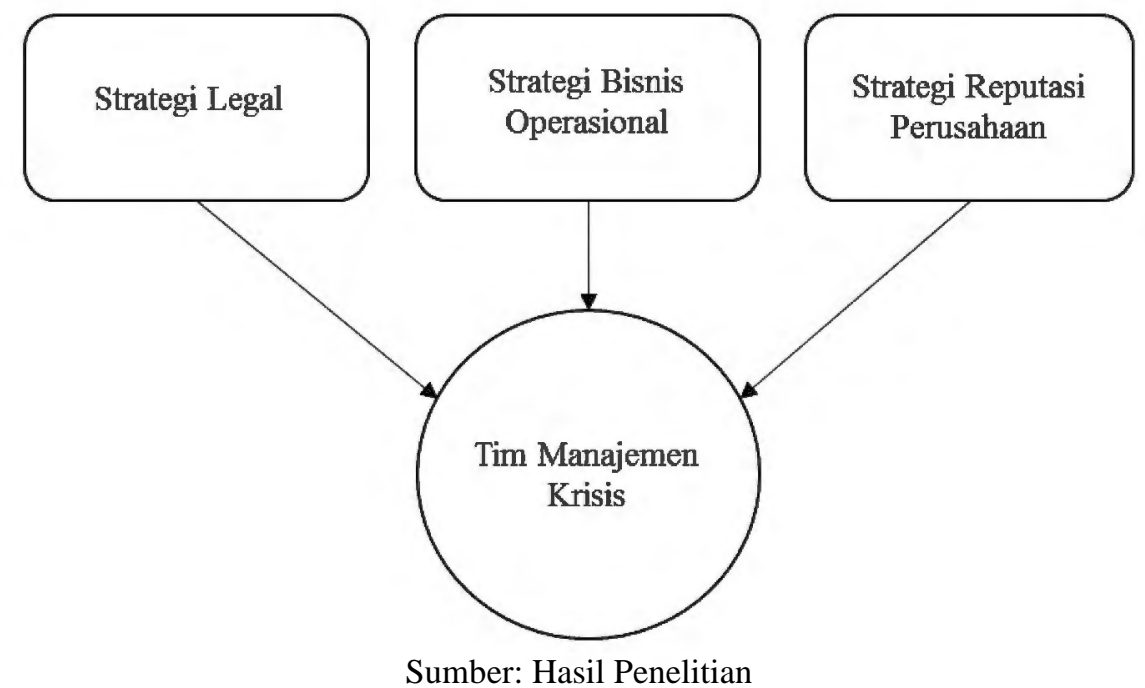


Dalam menjalankan strategi legal, komunikasi yang dilakukan PT A dalam tahap penyidikan mencakup komunikasi dengan 2 profesor dalam bidang hukum dari 2 institusi ternama untuk memberikan opini legal terkait permasalah yang yang dihadapi, yaitu mengenai perizinan yang masih sah karena adanya kendala dalam proses pengajuan. Opini tersebut kemudian diberikan kepada Bareskrim Polri sebagai bahan pertimbangan. Ketika dilakukan penetapan tersangka, maka dilakukan pembelaan hukum yang berbeda.

Dalam menjalankan strategi proses operasional, komunikasi yang dilakukan adalah komunikasi dengan pihak-pihak terkait untuk mendapatkan kronologi peristiwa dan mendorong keluarnya perizinan. Ada 2 kategori tindakan yang dibuat PT A dalam menjalankan strategi perlindungan reputasi perusahaan yaitu tindakan proaktif dan reaktif. Tindakan proaktif terdiri dari:

1. Memonitor dan mempersiapkan perangkat komunikasi media untuk pemangku kepentingan eksternal dan menugaskan juru bicara di Jakarta (level nasiona) dan daerah tempat krisis terjadi (lokal). Manajemen akan mendapatkan informasi mengenai standby statement (pernyataan perusahaan) untuk memastikan satu suara yang terintegrasi dalam perusahaan

2. Menggunakan network media untuk mengalihkan perhatian atau untuk meluruskan pesan. Upaya yang dilakukan meliputi kunjungan ke media besar di tingkat nasional dan menggelar diskusi dengan para editor

3. Corporate Affairs akan mengembangkan rencana aktivitas mingguan untuk melibatkan diri bersama pemangku kepentingan dan pemerintahan lokal

Tindakan proaktif selanjutnya mencakup poin yang telah dijabarkan pada strategi legal dan operasional, yaitu:

1. Mendapatkan pernyataan yang ditujukan untuk eksternal dari pengacara dengan maksud untuk menggunakannya sebagai senjata apabila kejadian terus berlanjut

2. Mendekati Bareksrim dan mengupayakan agar mereka mengerti cerita dari sisi PT A

3. Corporate Affairs menemui tim di pabrik untuk menekankan mengenai proses yang sedang berlangsung.

Selanjutnya, tindakan reaktif terdiri dari:

1. Mempersiapkan kronologi yang valid untuk media dan eksternal

2. Berdiskusi dan menginformasikan perusahaan induk setiap kali ada perkembangan

3. Mempersiapkan perangkat komunikasi internal untuk manajemen dan karyawan, dan menginformasikan perangkat pada perusahaan induk

Pada saat dilaksanakan sidang terbuka, PT A melaksanakan strategi yang direncanakan yaitu kunjungan kepada media dan forum lokal untuk memberikan informasi perkembangan kasus. Sehingga, apabila ada pemberitaan yang naik ke media, maka setidaknya ada dua sisi cerita yang diperlihatkan ke publik. Pesan utama yang disampaikan pada media atau pemangku kepentingan eksternal secara reaktif menekankan pada:

1. Reputasi baik PT A yang selama ini selalu patuh pada peraturan pemerintah 
2. Komitmen PT A yang pada saat itu sudah beroperasi selama lebih dari 22 tahun, untuk beroperasi dalam jangka panjang dengan mendukung karyawan dan komunitas di sekitar pabrik

3. Komitmen PT A untuk patuh pada peraturan lokal dan nasional, serta standar dan hukum industri. Maka dari itu, pada tahap penyidikan PT A bekerja sama dengan baik dengan otoritas dengan terus bersikap kooperatif selama proses berlangsung.

Dalam menyampaikan pesan mengenai kepatuhan PT A terhadap peraturan, ada 5 poin yang tercatat:

1. PT A telah mengajukan permohonan perpanjangan sebelum berakhirnya SIPA, berdasarkan peraturan pemetingah artinya PT A masih memiliki hak melanjutkan pengambilan air tanah.

2. Posisi tersebut didukung oleh pendapat hukum dari 2 profesor universitas ternama

3. PT A telah membayar pajak dari semua sumur

4. Terdapat beberapa kunjungan rutin ke pabrik dari instansi pemerintah yang bertanggung jawab mengawasi perizinan air

5. Belum ada sanksi dari instansi pemerintah terkait yang bertanggung jawab untuk perizinan air.

Dalam beberapa catatan legal dan rencana komunikasi media, tertulis juga beberapa pesan kunci yang menitikberatkan pada carut marutnya proses perizinan dan pembaruan perizinan, bahwa implementasi teknis yang terjadi di lapangan tidak dikomunikasikan secara transparan kepada industri. Dalam proses ini juga ada tindakan egosentris antar lembaga yang mempersulit perizinan. Berdasarkan alasan tersebut maka posisi pemohon perizinan yang sudah memenuhi syarat tidak seharusnya terancam karena adanya praktik buruk pada pemerintahan.

Sampai dengan tahun 2015, PT A juga memiliki rencana komunikasi media untuk kasus ini. Rencana tersebut berisi pemetaan media yang berdasarkan hubungan baik dan pengaruhnya. Tidak banyak pemberitaan di tahun 2015 yang dapat diidentifikasi melalui situs pencarian dibandingkan dengan pemberitaan di tahun 2015. Artinya, exposure dan minat terhadap kasus ini dapat dikatakan sudah meredup.

Tindakan lain pada strategi perlindungan reputasi adalah untuk membangun pemahaman bersama dengan para pemangku kepentingan utama. Untuk dapat melakukan ini, PT A melakukan pemetaan pemangku kepentingan yang didasarkan pada pengaruh mereka terhadap resiko komersial dan reputasi. Dalam tahap penyidikan, ada 3 kategori pemangku kepentingan utama yang perlu didekati oleh PT A: 1) LSM Konsorsium PJ, 2) kepolisian, dan 3) pemerintahan lokal. Tindakan yang dilakukan meliputi: pengiriman surat, penyampaian pesan utama, dan diskusi.

Pada praktiknya, PT A berusaha mencari tahu motif dari konsorsium PJ sebagai pelapor. Dari 7 kali pertemuan dapat disimpulkan bahwa motif konsorsium PJ sebenarnya adalah untuk menjadi vendor barang bekas dan sampah produktif di pabrik PT A. Namun konsorsium PJ menilai bahwa ada ketidakadilan dalam sistem tender yang dijalankan oleh PT A, sehingga 
barang bekas selalu dimonopoli oleh pihak yang bukan berasal dari komunitas sekitar. permasalahan.

PT A juga berusaha mendapatkan dukungan dari asosiasi dan jajaran kementerian yang meliputi: Kepala BKPM dan jajarannnya, Kementerian Perindustrian, Kementerian Koordinator Perekonomian, dan Presiden pada saat itu. Manajemen dan WS turun langsung dalam usaha tersebut. Dari data yang didapat, Asosiasi Pengusaha Indonesia (APINDO) membantu PT A dengan menuliskan surat kepada pemerintah lokal pada September 2014. Atas tuduhan perusakan lingkungan yang dilayangkan konsorsium PJ, yaitu penurunan permukaan air di area pemukiman masyarakat, PT A juga melakukan komunikasi dua arah dengan masyarakat, terutama para tokoh pimpinan dari warga RT 1,2, dan 3 dengan menceritakan sisi PT A dan membangun kepercayaan.

Dari hasil pertemuan dengan pimpinan warga, PT A berhasil mendapatkan pernyataan tertulis dari warga bahwa aktivitas PT A tidak mengganggu lingkungan di sekitar pabrik. PT A juga berhasil mendapatkan dukungan dari warga yang bersedia menjadi saksi dalam persidangan. Menurut WS, salah satu kunci keberhasilan dari komunikasi dengan konsorsium dan warga adalah penunjukan juru bicara yang tepat. Pada awal kasus berlangsung, TA ditunjuk untuk sebagai perwakilan PT A melakukan mediasi dengan komunitas. TA mengakui bahwa faktor jam terbang yang rendah dalam menghadapi krissi dan latar belakang budaya yang berbeda, menyebabkan perkembangan komunikasi menjadi terhambat. Seiring dengan perkembangan kasus, maka PT A menunjuk DS sebagai sosok yang mampu menjadi penengah antara PT A dan masyarakat.

DS memiliki pengalaman 20 tahun dalam sistem PT A, pernah menjadi bagian dalam tim IMCR, dan juga berasal dari provinsi tempat krisis berlangsung. DS dianggap mampu berbicara dalam bahasa masyarakat sekitar sehingga maksud dan tujuan baik PT A dapat dimengerti dengan mudah.

Komunikasi internal dilakukan dengan memberikan pernyataan tertulis kepada karyawan dari Presiden Direktur PT A melalui media komunikasi internal. Pesan utama yang disampaikan konsisten dengan apa yang disampaikan kepada pihak eksternal, bahwa:

1. PT A mematuhi semua hukum dan peraturan di manapun PT A beroperasi.

2. PT A menghormati proses investigasi yang berlangsung dan PT A bekerja seama dengan semua pihak berwenang untuk menyelesaikan masalah ini

3. PT A perduli dengan semua 12,000 karyawan di seluruh Indonesia. Dalam hal ini PT A akan selalu menyediakan semua sumber daya yang diperlukan hingga masalah selesai.

Pada pernyataan yang diberikan, PT A juga mempersilahkan karyawan untuk dapat langsung menghubungi pimpinan tim manajemen krisis, yaitu Direktur yang membawahi tim komunikasi, apabila memiliki pertanyaan lebih lanjut mengenai kasus tesebut. Melihat pernyataan yang dikeluarkan oleh PT A, PT A terlihat meyakini bahwa mereka berada dalam kelompok krisis victim atau korban. PT A memposisikan diri sebagai perusahaan yang selalu patuh pada aturan, dan kejadian yang tidak menyenangkan ini diakibatkan bukan diakibatkan oleh tindakan yang disengaja, akan tetapi karena proses administrasi perizinan yang rumit. PT 
A telah melaksanakan kewajiban yang seharusnya. Pesan yang disampaikan oleh PT A sesuai dengan legal standing yang dibuat.

Peneliti melihat bahwa reaksi yang diberikan dan strategi perbaikan reputasi yang dilaksanakan oleh PT A didasarkan pada pemahaman mereka mengenai kelompok krisis tersebut. Berdasarkan SCCT ada dua strategi yang digunakan PT A:

1. Diminish Response (reaksi mengurangi) dengan memberikan justification (pembenaran): Dalam hal ini PT A mengurangi tanggung jawab yang diembannnya dengan memberikan informasi bahwa PT A telah melaksanakan hal-hal sesuai ketentuan, hanya saja tidak mendapatkan tanggapan dari pemerintah setempat. PT A juga memberikan informasi bahwa berdasarkan hukum yang ada, SIPA tidak terhitung kadaluarsa apabila pengajuan pembaharuan sudah diajukan sebelum masa berlaku SIPA berakhir.

2. Deal response (reaksi menanggapi) dengan ingratiation (mempengaruhi orang lain dengan menjadi sosok yang lebih disukai: PT A mengingatkan pemangku kepentingan mengenai hal-hal baik yang telah dilakukan oleh organisasi, misalnya menyatakan bahwa PT A proaktif, tetap membayar pajak untuk pengambilan air, dan selama investigasi sangat kooperatif.

PT A juga menyatakan bahwa mereka berkomitmen penuh untuk menjalankan bisnis yang berkelanjutan dan dalam jangka panjang di Indonesia. PT A menjabarkan kontribusi apa saja yang sudah dilakukan dalam hal pengadaan lapangan kerja, investasi, dan program lingkungan juga sosial melalui aktivitas CSR. Strategi di atas disampaikan secara konsisten oleh PT A kepada para pemangku kepentingan. Cara ini dianggap bisa memberikan perspektif berbeda dan mengubah pandangan tanpa harus terlihat menyerang pelapor dan Bareksrim.

\section{Tahap paska-krisis}

PT A berada dalam posisi yang beruntung ketika pada akhirnya Undang-Undang Sumber Daya Air No.7 tahun 2004 dibatalkan oleh MK. Dengan terhentinya permasalahan hukum tersebut, maka krisis juga dianggap selesai karena tidak ada lagi tuntutan yang dapat dilayangkan baik oleh konsorsium ataupun Bareskrim. Berdasarkan pernyataan WS, saat ini PT A masih terus berupaya membangun hubungan baik dengan pemangku kepentingan, baik itu pemerintahan, maupun sekitar pabrik, melalui pemberian informasi perkembangan industri dan programprogram Corporate Social Responsibility (CSR).

Hasil observasi peneliti menunjukan bahwa sampai dengan saat ini PT A masih memiliki tim manajemen krisis dan melaksanakan penyuluhan IMCR untuk internal. Melalui departmen Corporate Affairs yang sekarang disebut sebagai Public Affairs and Communications, PT A melakukan monitor pemberitaan media secara berkala dan setiap bulannya, mengevaluasi isu untuk mendeteksi potensi krisis.

\section{Pembahasan}

PT A memiliki persiapan pada krisis yang baik apabila dilihat dari ketersediaan strategi manajemen krisis, seperti panduan alur proses komunikasi IMCR. Dokumentasi dari pelatihan IMCR dan rencana manajemen insiden juga menunjukan bahwa PT A memahami potensi apa 
saja yang bisa terjadi pada bisnis yang dijalani dan memahami tujuan dari proses komunikasi krisis.

Pada tahapan pra-krisis, kegagalan PT A adalah dalam melakukan deteksi sinyal dan pencegahan. Apabila hipotesa awal yang diajukan TA benar terjadi, maka gagasan FearnBanks (2011) mengenai pentingnya komunikasi teratur dan membangun budaya organisasi yang positif dan kondusif, menjadi penting adanya sebagai upaya pencegahan. Hal ini akan membantu karyawan memahami bahwa menjaga reputasi dan keberlangsungan bisnis perusahaan adalah tanggung jawab semua pihak dalam perusahaan. Apabila bisnis mengalami kerugian yang signifikan karena adanya kasus hukum yang menjerat, maka hal tersebut bisa secara langsung mempengaruhi karyawan.

Berdasarkan gagasan Fink (2013) mengenai identifikasi, isolasi, dan pengelolaan, PT A juga telah melakukan hal yang benar, meskipun hal ini juga bertentangan dengan gagasan Fink yang lainnya. Dengan memutuskan untuk tidak membentuk opini publik artinya PT A mampu memahami bagian mana dalam krisis tersebut yang harus ditangani dan mana yang dapat dikendalikan. PT A memilih untuk tidak memberikan perlawanan secara terang-terangan kepada Bareskrim untuk menghindari adanya pergesekan pendapat yang dapat berakibat lebih fatal.

Keputusan yang dibuat oleh pada tahap penyelidikan merupakan langkah yang berani, namun rasional. 3 strategi yang dibuat oleh PT A mempermudah PT A dalam mengambil tindakan. PT A tahu apa yang harus dilakukan dan siapa yang harus didekati agar kasus ini tidak semakin memburuk. Hal ini menunjukan bahwa PT A memahami mengenai penahanan atau isolasi krisis dan identifikasi pemangku kepentingan.

PT A mampu mengidentifikasi juru bicara yang tepat untuk setiap kategori pemangku kepentingan. Melihat adanya ketidakberhasilan di awal krisis, PT A dengan cepat mengambil tindakan. Begitu pula juru bicara yang dipilih untuk menghadapi karyawan internal dan pemerintahan. Menjadi benar adanya bahwa apabila pesan utama tidak bisa disampaikan dengan orang yang tepat, maka pesan tidak akan tersampaikan. Persepsi pemangku kepentingan tidak akan sesuai dengan realita yang ingin diperlihatkan oleh PT A.

PT A juga telah melakukan penahanan krisis agar sebisa mungkin krisis tersebut tidak mengganggu area lain dari operasional bisnis. Meskipun dampak dari krisis tersebut cukup besar dan bahkan sampai mengorbankan salah satu karyawan, namun tidak sampai mengganggu produksi dan penjualan produk baik di daerah tempat kasus berlangsung dan daerah lainnya. Artinya, PT A masih memegang kendali atas kejadian ini.

Dalam pemberian tanggapan, dilihat dari sangkaan yang dilayangkan oleh konsorsium PJ dan Bareskim Polri sebagai pemangku kepentingan utama pada kasus ini, peneliti menilai kategori krisis ini ada pada kelompok krisis preventable atau dapat dicegah. Hal ini dikarenakan bahwa kasus yang berawal dari permasalahan perizinan sebenarnya dapat dihindari apabila ada pemantauan terus-menerus yang terkait dengan perizinan. Bagaimanapun rumitnya 
administrasi pengurusan perizinan, PT A bertanggung jawab penuh atas kelengkapan dokumen legal. Peneliti meyakini bahwa internal PT A mengetahui ada konsekuensi yang dapat timbul atas masalah perizinan.

Dalam pembentukan pesan utama, dapat dikatakan PT A memberikan penjelasan yang akurat dan konsisten, meskipun tidak dengan segera karena kompleksitas kasus dan informasi yang sesuai fakta harus dikumpulkan terlebih dahulu. Begitu pula dengan pemilihan strategi pembenaran dan pemberian informasi mengenai sisi baik PT A dirasakan sangat membantu membentuk persepsi positif mengenai perusahaan.

Dalam pemberian pesan utama kepada karyawan, pernyataan bahwa PT A akan menyediakan semua sumber daya yang diperlukan untuk karyawan hingga masalah selesai memberikan rasa aman bagi karyawan, terutama untuk yang mengetahui adanya hukuman penjara dan denda bagi kepala pabrik PT A. Dapat dipastikan kejadian tersebut memicu kegelisahan, karyawan mungkin akan bertanya "apabila saya terlibat dalam kasus serupa, apakah perusahaan akan diam saja?”. Penyampaian pesan yang mengutamakan keamanan karyawan mampu meredakan potensi kegaduhan.

Pada akhirnya, meskipun tetap ada konsekuensi pidana yang dihadapi, namun PT A mampu meredam krisis agar tidak sampai pada level nasional seperti apa yang dialami CPI dan kerugian dari konsekuensi hukum yang lebih besar dapat dihindari. Reputasi tetap terjaga dengan adanya hubungan baik dengan para pemangku kepentingan dan pembelaan dari warga. Perhatian media semakin menurun untuk kasus ini dibandingkan dengan awal kasus dimulai dan kegiatan operasional tetap berjalan. Dapat dilihat bahwa meski tidak ideal, komunikasi krisis PT A dinilai efektif. .Namun perlu diingat bahwa strategi berbeda mungkin diperlukan apabila krisis berlanjut lebih lama.

\section{SIMPULAN}

Terlepas dari perbedaan kepercayaan peneliti mengenai atribusi akuntabilitas PT A terhadap kasus ini, peneliti menilai bahwa komunikasi krisis yang dilakukan oleh PT A sudah efektif. Kesimpulan didasarkan pada tujuan dari komunikasi krisis PT A dalam melindungi reputasi:

1. Pemberitaaan di media teredam dan tidak sampai menjadi kasus nasional seperti CPI

2. Hubungan baik dengan pemangku kepentingan terbangun, terutama dengan komunitas

3. Tidak adanya tuntutan lanjutan yang mengganggu operasional bisnis

Meskipun tidak ideal, komunikasi krisis PT A efektif membuktikan gagasan bahwa setiap krisis itu unik, dan perlakuan terhadap krisis harus disesuaikan dengan pilihan terbaik untuk kondisi pada saat itu. Ada beberapa hal yang dapat ditingkatkan ataupun diperbaiki dari penanganan dan komunikasi krisis kasus PT A, pertama adalah pencegahan pada tahap pra-krisis. Karyawan PT A harus mampu melihat potensi terburuk dari setiap kendala yang dihadapi dan apa saja kerugian yang dapat diakibatkan dari potensi tersebut, sehingga timbul sikap sigap dan berhati-hati dalam menjalankan tanggung jawabnya. 
Kedua, dalam pesan utama, PT A seharusnya dapat memberikan fakta mengenai dampak lingkungan yang dituduhkan, sehingga tidak ada celah bagi pelapor untuk kembali memperkarakan permasalahan tersebut. Penanganan paska krisis juga sangat penting untuk dijadikan disiplin pada setiap krisis yang terselesaikan. PT A harus dapat membuat sistem yang terorganisir untuk edukasi IMCR dan membangun hubungan baik dengan pemangku kepentingan di luar krisis. Hubungan baik dengan pemangku kepentingan akan menjadi investasi berharga bagi PT A di kemudian hari. Pada akhirnya analisis kasus sangkaan terhadap PT A mengenai pengambilan air tanah secara ilegal ini diharapkan dapat memberikan persepsi baru bagi organisasi yang mengalami kasus serupa.

\section{DAFTAR PUSTAKA}

Coombs, T. W. (2007). Crisis Management and Communications.

Coombs, W. (2012). Ongoing Crisis Communication: Planning, Managing, and Responding (3rd ed.). California: SAGE Publications

Creswell, J.W., (2009). Research design: Qualitative, quantitative, and mixed methods approaches (3 ed.).Sage Publications, thousand Oaks, USA

Fearn-Banks, K. (1996). Crisis Communications: A Casebook Approach. New York: Routledge

Fink, S. (1986). Crisis Management: Planning for the Inevitable. American Management Association

Fink, S. (2013). Crisis Communications: The Definitive Guide to Managing the Message. New York: McGraw-Hill.

Mitroff, I., Shrivastava, P., \& Udwadia, F.E. (1987). Effective Crisis Management. The Academy of Management Executive (1987-1989), Vol. 1, No. 4, pp. 283-292

Saputra, A. (2017, 23 Januari). MA Mentahkan Tuntutan Jaksa ke Manajer PT A

Stewart, T. (2002). Principles of research in communication. Boston: Allyn and Bacon. 